\section{Site records of softshell turtles (Chelonia: Trionychidae) from Barak Valley, Assam, northeastern India}

\author{
Kulendra C. Das ${ }^{1} \&$ Abhik Gupta ${ }^{2}$ \\ 1,2 Department of Ecology and Environmental Science, Assam \\ University, Silchar, Assam 788011, India \\ Email: ${ }^{1}$ kcdas23@rediffmail.com (corresponding author), \\ 2abhik.eco@gmail.com
}

Eight species of turtles belonging to the family Trionychidae (Reptilia: Chelonia) are known to occur in India and include Nilssonia gangetica, N. hurum, $N$. leithii, $N$. nigricans, Chitra indica, Amyda cartilaginea, Pelochelys cantorii and Lissemys punctata (two subspecies - punctata and andersonii). All the species barring $N$. leithii and $P$. cantorii have been reported from parts of Assam, Meghalaya and Mizoram in northeastern India (Das 1990, 1996; Bhupathy et al. 1992; Frazier \& Das 1994; Choudhury 1995; Datta 1998; Sengupta et al. 1998; Pawar \& Choudhury 2000; Praschag \& Gemel 2002). However, most of the records are from the Brahmaputra plains of Assam and adjoining areas in lower eastern Himalaya, parts of Meghalaya and Mizoram. There is only a market survey record of trionychid species (Das \& Gupta 2004) and diversity and ecology of chelonians (Das 2008) from the Barak Valley region in the southern part

\section{Date of publication (online): 26 April 2011 \\ Date of publication (print): 26 April 2011 \\ ISSN 0974-7907 (online) | 0974-7893 (print)}

Editor: Indraneil Das

\section{Manuscript details:}

Ms \# 02487

Received 18 June 2010

Final received 21 December 2010

Finally accepted 07 February 2011

Citation: Das, K.C. \& A. Gupta (2011). Site records of softshell turtles (Chelonia: Trionychidae) from Barak Valley, Assam, northeastern India. Journal of Threatened Taxa 3(4): 1722-1726.

Copyright: () Kulendra C. Das \& Abhik Gupta 2011. Creative Commons Attribution 3.0 Unported License. JoTT allows unrestricted use of this article in any medium for non-profit purposes, reproduction and distribution by providing adequate credit to the authors and the source of publication.

Acknowledgements: We are grateful to the G.B. Pant Institute of Himalayan Environment and Development, Almora, and UGC, New Delhi, for funding assistance.

OPEN ACCESS | FREE DOWNLOAD of Assam, which is geographically distinct from the Brahmaputra Valley, being separated from the latter by the Borail range of mountains and the Meghalaya Plateau, and is a part of the Surma Valley of Sylhet District of Bangladesh, which in turn is a part of the Meghna Drainage. The present study, conducted during July 2002 to June 2007, reports for the first time the occurrence of four species of trionychid turtles, Nilssonia gangetica, N. hurum, Chitra indica, and Lissemys punctata andersonii from 57 sites in the three Barak Valley districts of Cachar, Hailakandi and Karimganj in Assam, northeastern India, based on both live specimens and carapace records.

Materials and Methods: The survey was conducted during July 2002 to June 2007, in the Barak Valley region of Assam that comprises the three districts of Cachar, Hailakandi and Karimganj $\left(24^{0} 12^{\prime}-25^{\circ} 8^{\prime} \mathrm{N} \& 92^{0} 12^{\prime}-93^{0} 15^{\prime} \mathrm{E}\right)$. Records of turtles were made through direct sightings and by questioning the people in different areas, especially the turtle hunters. Live specimens were collected from the turtle hunters and fishermen as well as from the village markets and released after taking photographs and making morphometric measurements. Carapaces and/or plastrons were collected from the villages near the study sites. Identification was done using standard keys (Smith 1931; Das 1991). As all the trionychid species reported here are endangered and protected, photographs of live specimens and some carapace samples are deposited in the Animal Biodiversity Museum of the Department of Ecology \& Environmental Science, Assam University, Silchar, India.

Results and Discussion: During the survey, four species of trionychids, Nilssonia gangetica (Image 1) (AU-Ecol/ABM/Reptilia/Chelonia/ng-1a), N. hurum (Image 2) (AU-Ecol/ABM/Reptilia/Chelonia/nh-2a), Chitra indica (Image 3) (AU-Ecol/ABM/Reptilia/ Chelonia/ci-3a), and Lissemys punctata andersonii (Image 4) (AU-Ecol/ABM/Reptilia/Chelonia/lpa-6a) were recorded from 57 sites in the three Barak Valley districts of Cachar, Hailakandi and Karimganj in Assam, northeastern India (Fig. 1, Table 1). Of these four species, Nilssonia gangetica (Cuvier, 1825) is Vulnerable (ATTWG 2000), which was first recorded 
in Assam by Bhupathy et al. (1992) from the Kaziranga, Orang and Nameri National Parks in Brahmaputra Valley, followed by records from Sibsagar and north Lakhimpur districts and the Dibru Saikhowa National Park in Tinsukia District (Choudhury 1995). Dutta (1997) reported this species from Dhubri District, while Sengupta et al. $(1998,2000)$ recorded its occurrence in Sibsagar, Dhubri and Kamrup districts. Ahmed et al. (2009) reported this species from Barak Valley. In the Barak Valley, live specimens of this species have been found in 25 sites, along with carapace records from 15 sites, in Cachar, Hailakandi and Karimganj districts. The habitats include rivers, streams in plains and foothills, ox-bows and floodplain lakes (beels). The size (Straight Carapace Length - SCL) and weight of the specimens ranged from $14-57 \mathrm{~cm}$ and $0.4-20 \mathrm{~kg}$, respectively.

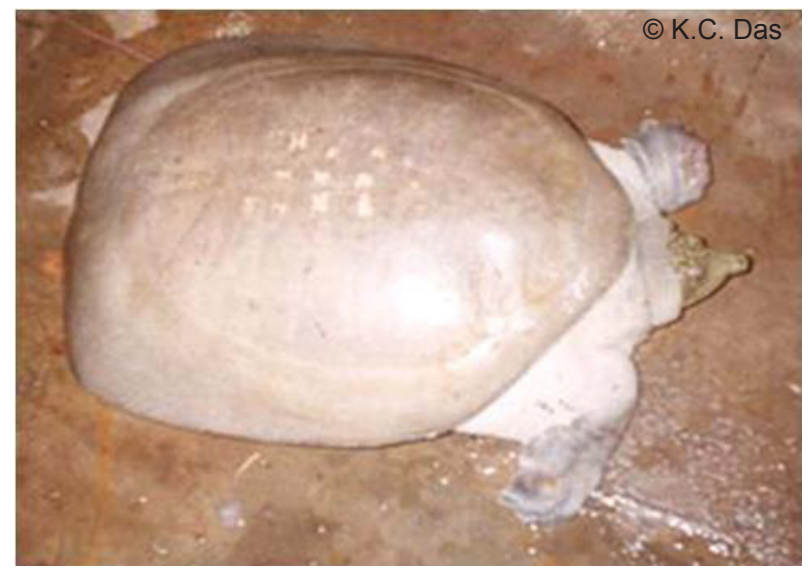

Image 1. Nilssonia gangetica

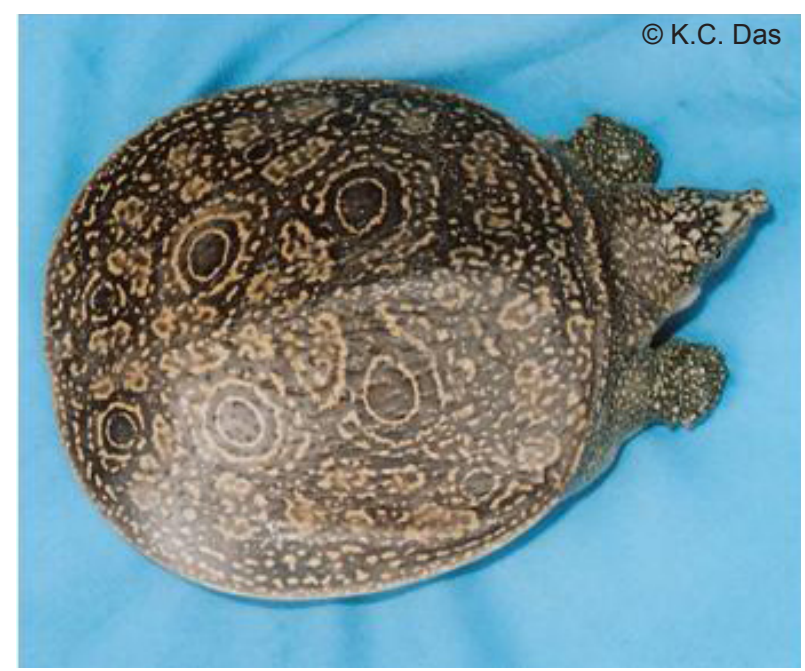

Image 2. Nilssonia hurum

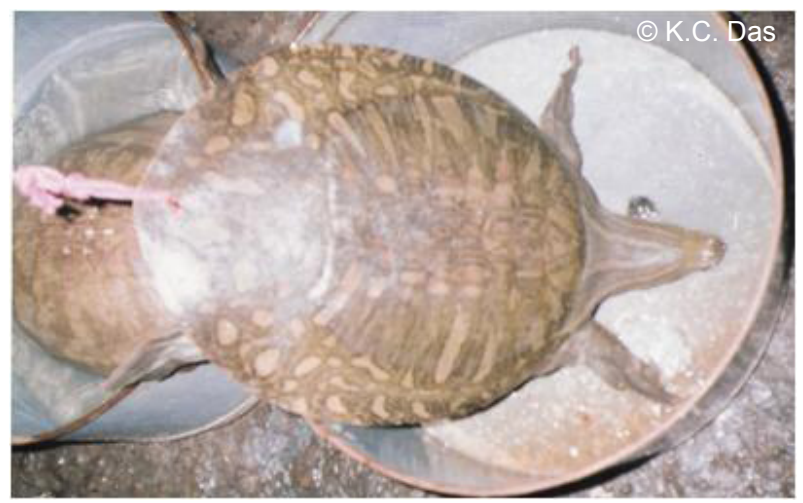

Image 3. Chitra indica

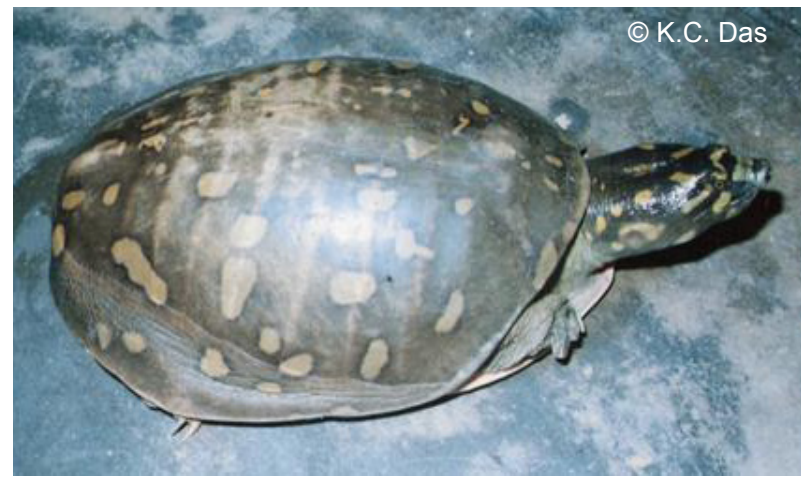

Image 4. Lissemys punctata andersonii

Nilssonia hurum (Gray, 1831) is Vulnerable according to the IUCN Red List of Threatened Species (ATTWG 2000), was earlier recorded from Tinsukia, Bokakhat, north Cachar Hills, Kaziranga National Park, Guwahati, Dhubri and Kamrup districts (Bhupathy et al. 1992; Frazier \& Das 1994; Barman 1996; Dutta 1997; Sengupta et al. 2000). Ahmed et al. (2009) recorded the distribution of this species throughout Assam. The present study reports its occurrence in 14 sites (live specimens from 10 and carapace from four sites) in all three Barak Valley districts from rivers, streams, ox-bows and floodplain lakes. The SCL and weight of the specimens ranged from $8-33 \mathrm{~cm}$ and 0.1 $3.5 \mathrm{~kg}$, respectively.

Chitra indica (Gray, 1831) is Endangered (ATTWG 2000), the rarest Trionychid in this area, having been recorded from six sites in Cachar and Karimganj districts. Live specimens were recorded from Fulertal upstream of Barak River, downstream at the forking of Barak into Surma and Kusiyara near the India-Bangladesh border, and from a large ox-bow still having connections with Barak River at Baskandi. 


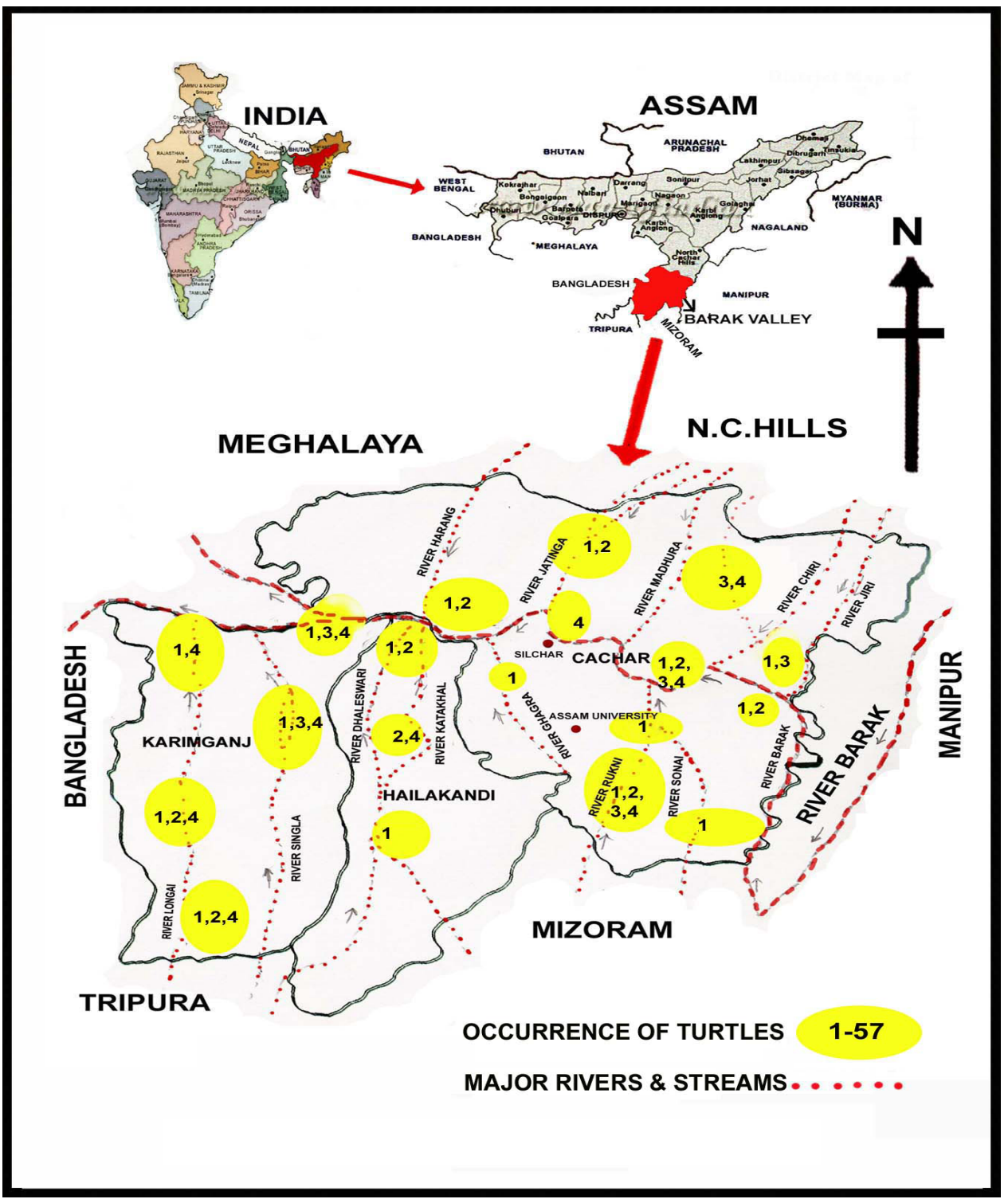

Figure 1. Map of Barak Valley showing sites of occurrence of Trionychid turtles.

1 - Nilssonia gangetica; 2 - N. hurum; 3 - Chitra indica; 4 - Lissemys punctata andersonii; $\rightarrow$ - Arrow signifies the flow of direction of river.

The SCL and weight ranged from $26-75 \mathrm{~cm}$ and $1.6-$ $40 \mathrm{~kg}$, respectively. Fishermen in Sylhet district of Bangladesh call Chitra indica "Dhush Kassim", referring to its tendency to "hit blows with its head" (Frazier \& Das 1994). The Bengali fishermen and turtle hunters of Barak Valley, who speak the same dialect of Bengali, also call this turtle "Dhush Kasim" or "Gutasol", the latter word also referring to its tendency to thrust its head in aggression. Similarly, Lissemys punctata andersonii (Webb, 1980) is also called "Til Kasim" because of its blotched appearance. L. punctata andersonii has been recorded from 23 sites in the Valley, including live records from 12 sites, the
SCL and weight ranging from $6.5-25 \mathrm{~cm}$ and $0.1-2.8$ $\mathrm{kg}$, respectively. Previous records in Assam are from Kaziranga National Park (Das 1990; Bhupathy et al. 1992), and Kamrup (Sengupta et al. 2000), and from Ranikor in West Khasi Hills, Meghalaya (Das 1990). Das (1990) assigned all the specimens from Assam seen by him to the subspecies andersonii because of their yellow-blotched heads and carapaces. A similar colour pattern is seen in all the specimens from Barak Valley examined by us. Interestingly, Talukdar (1979) recorded the subspecies punctata from Brahmaputra Valley (Talukdar followed Smith's concept for the 2 subspecies. Webb 1980 felt that the yellow-spotted 
Table 1. Site records of softshell turtles from Barak Valley, Assam, northeastern India

Site Records

1. Nilssonia gangetica (Bengali ${ }^{*}$ - Kasrong / Jat Kasim; Dimasa - Kusang)

Cachar District: (Town 244ㅇ'N \& 92047’E)

Rivers: Barak River at Lakhipur $\left(24^{\circ} 47^{\prime} \mathrm{N} \& 93^{\circ} 00^{\prime} \mathrm{E}\right)$ on 8.xi.2003 (2L); Fulertal (24047'N \& 93001'E) on 14.viii.2002 (1L, 2C) and on 27.x.2006 (1L,1C); Lalmatidahr (24049'N \& 92051'E) on 7.i.2004 (2L); Jatingamukh (Jatinga River - Barak River confluence) on 9.xii.2002 (1L); Sonai River at Monierkhal on 12.ii.2003 (1L); Amraghat on 12.ii.2003 (1L); Kaptanpur on 24.vii.2002 (1L, 2C) and 11.v.2005 (1L); Dolu River at Dolu T.E. on 14.xii.2002 (1L); Karati River at Mohanpur on 27.iii.2003 (1L, 1C) and 13.ix.2006 (1L); Jiri River at Mirpur on 28.xi.2002 (1C) Jatinga River at Balacherra on 9.xii.2002 (1L).

Streams: Khulicherra $\left(24^{0} 29^{\prime} \mathrm{N} \& 2^{\circ} 50^{\prime} \mathrm{E}\right)$ on 09.i.2004 (1L,

1C) (Tributary of Rukni River).

Floodplain Lakes (Beels): Bagiala on 1.viii.2002 (1L, 1C) and 23.v.2003 (1L,1C); Sheorartal on 2.viii.2002 (2C); Padmabee on 22.vii.2002 (1L) (Rukni RC); Ganganagar on 12.ii.2003 (2C) (Sonai RC); Baukarabeel on 27.vii.2003 (2C) (Ghagra RC); Balirbond on 19.viii.2003 (2C) (Barak RC).

Ox-Bows (Anuas): Satkorakandi on 20.xii.2003 (2C) and 25.xii.2003 (2L) (Sonai RC); Baskandi (24048'N \& 92 ${ }^{\circ} 54^{\prime} \mathrm{E}$ ) on 06.i.2004 (2L); Siyaltek on 24.viii.2002 (1C); Fulbari on 24.viii.2002 (1C) (Barak RC).

Reservoirs: Haticherra on 14.xi.2003 (1L, 1C).

Hailakandi District: (Town $24^{\circ} 40^{\prime} \mathrm{N} \& 9^{\circ} 33^{\prime} \mathrm{E}$ )

Rivers: Barak River at Katakhal $\left(24^{\circ} 49^{\prime} \mathrm{N} \& 92^{\circ} 39^{\prime} \mathrm{E}\right)$ (Katakhal River - Barak River confluence) on 27.xii.2002 (1L, 2C); Kalinagar on 30.xi.2002 (2L); Polarpar River-Barak River confluence on 23.viii.2002 (1L); Panchgram (24052'N \& 92035'E) on 23.viii.2002 (1L, 2C); Katakhal River at Monipur T.E (24.24' $\mathrm{N}$ \& $92^{\circ} 33^{\prime} \mathrm{E}$ ) on 13.iii.2003 (1C).

Karimganj District: (Town 24051'N \& 92022'E)

Rivers: Barak River at Haritikar (near bifurcation of Barak River into Surma River and Kusiara River near India-Bangladesh border) on 27.vii.2003 (1C); Kusiara River at Bhangabazar $\left(24^{\circ} 51^{\prime} \mathrm{N}\right.$ \& $\left.92^{\circ} 28^{\prime} \mathrm{E}\right)$ on 26.viii.2003 (1L, 2C); Lakhibazar (24 $54^{\prime} \mathrm{N}$ \& 92 $\left.15^{\circ} \mathrm{E}\right)$ on 19.i.2004 (3C); Longai River at Lowairpoa $\left(24^{\circ} 28^{\prime} \mathrm{N} \& 92^{\circ} 19^{\prime} \mathrm{E}\right)$ on 04.vi.2003 (1C); Jherjheri on 6.xi.2003 (1C); Rangamati on 05.vi.2003 (1L, 1C).

Streams: Bazaricherra $\left(24^{\circ} 26^{\prime} \mathrm{N} \& 92^{\circ} 19^{\prime} \mathrm{E}\right)$ on 4.vi.2003 (2L) (Tributary of R. Longai).

Floodplain Lakes (Beels): Ratabeel at Rakeshnagar on 20.vii.2003 (1L, 3C); Sonbeel at Ramkrishnagar Kalibari (24032' N \& $92^{2} 25^{\prime} \mathrm{E}$ ) on 15.vii.2003 (2L, 2C) (Singla RC); Balidharabeel on 18.i.2004 (1C); Tesuabeel on 25.vii.2003 (1C) (Kusiara RC); Putnibeel on 12.vi.2003 (1C) (Longai RC).

\section{Nilssonia hurum (Bengali - Dhum Kasim, Bukum)}

\section{Cachar District: (Town 24049'N \& 92 ${ }^{\circ} 47^{\prime} \mathrm{E}$ )}

Rivers: Barak River at Lakhipur on 08.xi.2003 (3L); Rukni River at Hawaithang (24030'N \& 92 $\left.2^{\circ} 48^{\prime} \mathrm{E}\right)$ on 01.viii.2002 (4C); Dholai $\left(24^{\circ} 35^{\prime} \mathrm{N} \& 9^{\circ} 50^{\prime} \mathrm{E}\right)$ on 22.vii.2003 (3L); Madhura River at Lathigram (24050'N \& 92050'E) on 17.v.2003 (1L, 1C); Dolu River at Dolu T.E. on 14.xii.2002 (1C).

Streams: Jhingacherra (Tributary of Jatinga River) at Balacherra on 24.i.2003 (1L).

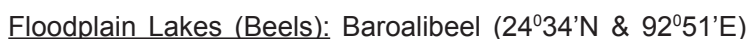
on 03.viii.2002 (2L) and 24.i.2004 (2L, 1C) (Rukni RC).

Ox-Bows (Anuas): Satkorakandi on 20.xii.2003 (2L) (Sonai RC); Baskandi on 13.vi.2005 (2L) (Barak RC).

Reservoirs: Dolu on 14.xii.2002 (1C)

Hailakandi District:

Rivers: Barak River at Polarpar River - Barak River confluence on 23.viii.2002(1C); Katakhal River at Kuchila on 7.iv.2003 (1L); Matijuri on 24.ix.2002 (1C).

Karimganj District:

Streams: Bazaricherra on 20.viii.2002 (2L) (Tributary of Longai River)

\section{Chitra indica (Bengali* - Dhush Kasim; Gutasol)}

\section{Cachar District:}

Rivers: Barak River at Fulertal on 14.viii.2002 (1L) and 27.x.2006 (1L); Chiri River at Harinagar $\left(24^{\circ} 55^{\prime} \mathrm{N} \& 93^{\circ} 06^{\prime} \mathrm{E}\right)$ on 30.vi.2004 (1C).

Floodplain Lakes (Beels): Harinbeel on 26.vii.2002 (1C) (Rukni RC).

Ox-Bows (Anuas): Baskandi on 15.xii.2003 (2L) (Barak RC) Karimganj District:

Rivers: Barak River at Haritikar (near bifurcation of Barak River into Surma River and Kusiara River near India-Bangladesh border) on 19.vii.2003 (1L).

Floodplain Lakes (Anuas): Ratabeel at Rakeshnagar on 20.vii.2003 (1C) (Singla RC).

4. Lissemys punctata andersonii (Bengali* - Sip Kathua/ Kasim, Til Kasim)

\section{Cachar District:}

Rivers: Barak River at Lalmatidahr on 7.i.2004 (2L); Chiri

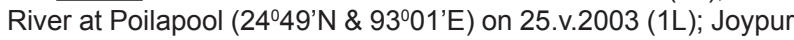
( $\left.24^{\circ} 52^{\prime} \mathrm{N} \& 9^{\circ} 03^{\prime} \mathrm{E}\right)$ on 26.v.2003 (2L); Karati River at Mohanpur on 19.iii.2004 (1C); Rukni River at Hawaithang on 1.viii.2002 (2L, 1C).

Floodplain Lakes (Beels): Kalahaor on 9.i.2004 (3C); Bagiala on 1.viii.2002 (3L); Sheorartal on 2.viii.2002 (2C); Baroalibeel on 24.i.2004 (2L, 1C) and 3.viii.2002 (2L,1C); Suktala on 22.vii.2002 (4C); Harinbeel on 26.vii.2002 (2L) (Rukni RC); Masughat on 14.xii.2003(2C) (Barak RC). $\mathrm{RC})$.

Ox-Bows (Anuas): Satkorakandi 20.xii.2003 (3C) (Sonai

Reservoirs: Dolu on 14.xii.2002(2C)

Hailakandi District:

Rivers: Katakhal River at Kuchila on 7.iv.2003 (2L, 1C); Monipur T.E. on 13.iii.2003 (1C)

Karimganj District:

Rivers: Barak River at Haritikar (near bifurcation of Barak River into Surma River and Kusiara River near India-Bangladesh border) on 19.vii.2003 (1L); Longai River at Lowairpoa on 5.vi.2003 (2L).

Floodplain Lakes (Beels): Sonbeel at Ramkrishnagar Kalibari on 15.vii.2003(3C) (Singla RC); Balidharabeel on 18.i.2004 (1C); Bhekbhekibeel at Latu on 18.i.2004 (2L, 2C) (Kusiara RC); Putnibeel on 12.vi.2003 (2L, 1C); Solgoi-Sadhugutibeel (24031' $\mathrm{N}$ \& 92019'E) on 18.vii.2003 (2C) (Longai RC).

Abbreviations: L - live specimens; C - carapace; T.E. - tea estate; RC - river catchment; (\#L or \#C) - (\# signifies number of live specimens or carapaces record) along with date of documentation; GPS Location available only for a few sites.

* Dialect of Bengali spoken in Barak Valley and the neighbouring Sylhet District of Bangladesh. 
form should bear the name andersonii). L. punctata andersonii is a fairly common species in Barak Valley, and frequents lentic systems such as floodplain lakes and ox-bows, besides rivers.

Thus the present records, especially those of live specimens, from Barak River, its various tributaries, as well as the floodplain lakes and ox-bows, indicate that the softshell turtles are distributed much further upstream in the Meghna River system of Bangladesh of which Barak forms a part. N. gangetica is known to be able to survive in artificial lentic water bodies like 'jheels' that completely dry up in the lean season (Frazier \& Das 1994). The numerous floodplain lakes and ox-bows that are associated with the meandering courses of Barak River and its tributaries, and maintain links with the river in the monsoon, are also found to serve as important turtle refuges, especially for species like $N$. gangetica and L. punctata andersonii, several records of these two species having been made in the floodplain lakes and ox-bows. $N$. hurum, although less frequently encountered than $N$. gangetica, appears to be distributed more upstream into the foothill stretches of rivers. It is likely that this species also occurs in the upper reaches of Rukni River inside Mizoram, as reported by the Dimasa turtle hunters who make annual forays into the upstream areas of this river. However, the carapace records should be treated as possible sites where these turtles may be found and not as definitive site records as had also been pointed out by Frazier \& Das (1994). The villagers in this area hang turtle shells in their cow sheds and homes as they ascribe some magico-religious properties to them (Gupta 2002) and might, therefore, import them from distant places and not necessarily procure them from a nearby river or lake.

\section{REFERENCES}

Ahmed, M.F., A. Das \& S.K. Dutta (2009). Amphibians and Reptiles of Northeast India - A Photographic Guide. Aaranyak, Guwahati, India, xiv+168pp.

ATTWG (Asian Turtle Trade Working Group) (2000). Nilssonia gangetica. In: IUCN 2010. IUCN Red List of Threatened Species. Version 2010.4. <www.iucnredlist. org $>$. Downloaded on 18 February 2011.

Barman, R. (1996). Occurrence of Indian peacock softshell turtle in Guwahati University campus. Journal of the Bombay Natural History Society 93(3): 591.
Bhupathy, S., B.C. Choudhury \& M.O. Moll (1992). Conservation and management of Fresh Water Turtles and Land Tortoises of India. Technical Report, May 1991-July 1992. Wildlife Institute of India, Dehradun.

Choudhury, A. (1995). Turtles recorded in Dibru Saikhowa Wildlife Sanctuary, Assam. Journal of Ecological Society 8: 3-39.

Das, I. (1990). Distributional records for the chelonians from North eastern India. Journal of the Bombay Natural History Society 87: 91-97.

Das, I. (1991). Colour Guide to The Turtles and Tortoises of the Indian Subcontinent. R \& A Publishing Limited, Portishead, U.K., 133pp.

Das, I. (1996). Biogeography of the Reptiles of South Asia. Krieger Publishing Company, Malabar, Florida, 87pp.

Das, K.C. (2008). Diversity and Ecology of chelonians and their conservation in Barak Valley, Assam, North East India. $\mathrm{PhD}$ Thesis. Department of Ecology and Environmental Science, Assam University, Silchar, 213pp.

Das, K.C. \& A. Gupta (2004). Turtle market survey in Silchar, Assam, northeastern India. Turtle and Tortoise Newsletter 8: 18-17.

Datta, A. (1998). Records of turtles from Pakhui Wildlife Sanctuary, Arunachal Pradesh, northeastern India. Journal of the Bombay Natural History Society 95: 121-123.

Dutta, S. (1997). Fresh water turtles and land tortoises of Dhubri District. Zoos' Print Journal 12(6): 1-4.

Frazier, J.G. \& I. Das (1994). Some notable records of testudines from the Indian and Burmese subregions. Hamadryad 19: 47-66.

Gupta, A. (2002). The beleagured chelonians of northeast India. Turtle and Tortoise Newsletter 6: 16-17.

Pawar, S.S. \& B.C. Choudhury (2000). An inventory of Chelonians from Mizoram, northeastern India: new records and some observations of threats. Hamadryad 25(2): 144158.

Praschag, P. \& R. Gemel (2002). Identity of the black softshell turtle Aspideretes nigricans (Anderson, 1875) with remarks on related species. Faunistische Abhandlungen Staatliches Museum Fur Tierkunde In Dresden 23: 87-116.

Sengupta, S., M. Baruah \& N.K. Choudhury (1998). Report on turtles of Pobitora Wildlife Sanctuary. NATCON 10(2): 209-210.

Sengupta, S., N.K. Choudhury, N. Barua, S. Saikia \& B. Hussain (2000). Turtle fauna of Kamrup District, Assam. India, Tropical Zoology 1(1): 138-142.

Smith, M.A. (1931). The Fauna of British India, Ceylon and Burma: Amphibia and Reptilia. Vol. I-Loricata, Testudines, Taylor and Francis Ltd., London, 185pp.

Talukdar, S.K.(1979). Lissemys punctata punctata (Bonnaterre) (Testudines: Trionychidae): an addition to the chelonian fauna of the Brahmaputra Drainage, Assam. Indian Journal of Zootomy 20(3): 181.

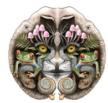

